\title{
THE DIFFICULTY IN JOHN XIII. 1.
}

By S. M. PROVENCE, D.D.

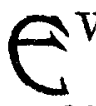

VERY careful student sees the lack of connection between the affirmation in John xiii: 1 and the adverbial clauses by which it is modified. The following renderings show that the lack has not yet been supplied:

Authorized Version: Now before the feast of the passover, when Jesus knew that his hour was come that he should depart out of this world unto the Father, having loved his own which were in the world, he loved them to the end.

American Bible Union: And before the feast of the passover, Jesus knowing that his hour has come that he should depart out of this world to the Father, having loved his own who were in the world, he loved them to the end.

Canterbury Revision: Now before the feast of the passover, Jesus knowing that his hour was come that he should depart out of this world unto the Father, having loved his own who were in the world, he loved them to the end.

Norton's Translation: But Jesus, before the feast of the Passover, knew that the hour had come for him to pass from this world to the Father; and having loved his own who were to remain in this world, he loved them to the last.

Twentieth Century Translation: Before the Passover Festival began, Jesus knew that the time had come for him to leave the world and go to the Father; but he had loved those who were his own in the world, and he loved them to the last. 
Latin (from Leusden's edition) : Ante antem diem festum Pascha, sciens Jesus quia venit ejus hora, ut transiret ex mundo hoc ad Patrem, diligens proprios qui in mundo, in finem dilexit eos.

French (edition of Marten): Ov, arant la fête de Pâque, Jésus sachant que son heure était venue pour passer de ce monde au Père, comme il avait aimé les siens, qui étaient au monde, il les aima jusq' à la fin.

So all the Greek editions that I know of punctuate. For the reader's convenience the Greek text is here given:

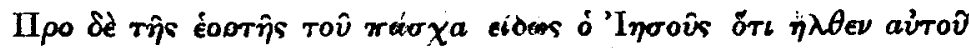

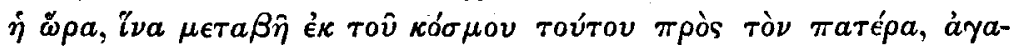

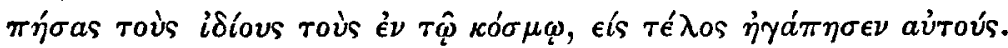

It will be observed that in the effort to connect the main verb $\eta_{\gamma} a^{\prime} \pi \eta \epsilon \nu$ with its modifying clauses Professor Norton and the Twentieth Century translators have taken liberties with the text. Both make the participle eidós a finite verb, modifying it by $\pi \rho \dot{o} \delta \epsilon \tau \hat{\eta} s ~ \dot{\epsilon} o \rho \tau \hat{\eta} \varsigma$, and both suppiy a conjunction. The Twentieth Century translators treat $\dot{a} \gamma a \pi \eta$ бas in the same way, supplying a conjunction before and after, making three principal verbs in the verse, with as many distinct affirmations without logical connection. It is allowable, to be sure, to translate a participle by a finite verb, but some particle must be introduced which will preserve the relationship of the parts of the sentence.

According to the common punctuation the verse ends

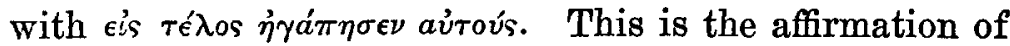
the sentence thus formed: "them he loved to the uttermost,' aúroús being emphatic by position. This affirmation is modified by three adverbial clauses: $1 . \pi \rho 0$ i $\hat{\eta}$ s

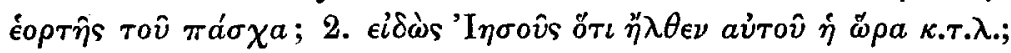

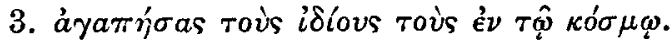

By testing these separately it will be seen that they do not bear any logical connection with the verb a' a'a $\pi \sigma \epsilon \nu$. 'Before the feast of the passover Jesus loved them to the 
end.' 'Jesus knowing that his hour was come to leave this world and return to the Father, loved them to the uttermost.' 'Having loved his own who were in the world he loved them to the uttermost.' Even for this last combination no good reason is apparent. Commentators have had no little trouble with these clauses, especially

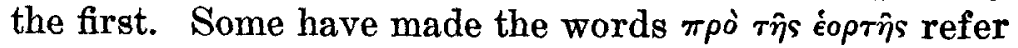
to the divine fore-knowledge, and some have carried the occasion back to the social function in Bethany. With great unanimity they have discussed the declaration of love, but why "before the feast""

Winer (Gram., p. 572) says that the verse "contains no anacoluthon" and that "the difficulty must be disposed of hermeneutically." But as to how this is to be done he offers no suggestion. "Anacoluthon (ibid., p. 566) occurs when the construction with which a sentence began is not grammatically pursued,-either because the writer is wholly diverted from the structure adopted at the beginning by something intervening (especially by parenthesis) or because for the sake of a preferable mode of expression he frames the close of his sentence otherwise than the commencement required."

"The difficulty," however, vanishes if the words $\epsilon$ 's

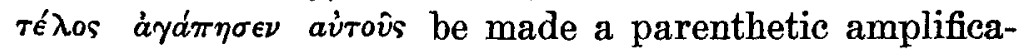

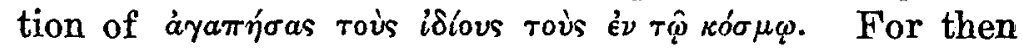
the sentence will go on to the end of the fourth verse, and the predicate will begin with éreiperal. The modifying clauses will then fall into their proper relations and the whole sentence, notwithstanding its length becomes perfectly clear. This will appear if a somewhat free translation be given: "But (or 'and,' $\delta \grave{e ̀ ~ b e i n g ~ m e r e l y ~ a n ~}$ introductory particle) before they began to eat the Paschal supper, Jesus, knowing that the time was at hand when he would leave this world and return to the Father, although he loved his friends who must remain in the world (them he loved to the last), and the feast being 
ready, the devil having previously put it into the heart of Judas Iscariot, Simon's son, to betray him, knowing that the Father has given all things into his hands and that he came from God, rises from the table and lays off his cloak; and taking a towel he wound it around his body."

This fits all the circumstances. Jerusalem was crowded with visitors who had come to the great festival. Every householder who had a guest-chamber had no doubt furnished it with a view to getting a good rent for it on this occasion. Our Lord knew where there was such a room as he required. He was the host of the evening. There was apparently no servant. The washing of the feet was one of the necessities of the festival. The company had left their sandals outside. Their feet must be washed. The necessity had grown a custom of hospitality. Perhaps the question of priority arose about this very service. Jesus turned the whole matter to account by taking the service upon himself, and that, too, naturally, before the eat-

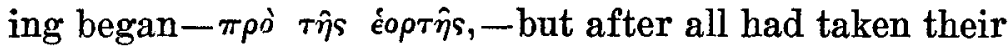
places, reclining, with their feet projecting over the end of the couches. This service completed, he resumes his place and his table-talk begins, during which Judas is dismissed.

It seems impossible to divide the long sentence (vv. 1-4) without destroying the relation of the parts. This difficulty was seen long before the division into verses was made. An evidence of this is the insertion of ' $\dot{o} \mathrm{I} \eta \sigma o \hat{s} s$ in the third verse after $\epsilon i \delta \omega s$ as in the first line of verse one. Two ways are suggested here by which the tension between the subject and the predicate may be relieved: First, by withholding the subject until the predicate is reached; e. g., But before they began to eat the paschal supper, knowing that the time was at hand when he would leave this world and return to the Father, although he loved his friends who must remain in the world (them he loved to the last), and the feast being ready, the devil 
having previously put it into the heart of Judas Iscariot, Simon's son, to betray him, knowing that the Father has given all things into his hands, and that he came from God and is about to return to God, Jesus rises from the table, etc. Second, by recasting the entire sentence; e. g., Before they began to eat the Paschal supper, Jesus arises from the table and puts off his cloak; and taking a towel he wound it around his body. He knew that the time was at hand when he would leave this world and return to the Father, although he loved his friends, who must remain in the world (them he loved to the last). Moreover, the feast was ready and the devil had previously put it into the heart of Judas Iscariot, Simon's son, to betray him. Jesus knew, too, that the Father had given all things into his hands, and that he had come from God and was about to return to God. So he then pours water into the basin (which was part of the furnishing and put there for that purpose, hence the definite article), and began to wash the disciples' feet and to wipe them with the towel which he had around his waist. This seems to preserve the meaning of the evangelist and to put the whole incident into its proper relation with what follows. He is telling the story of the last supper and of the washing of the feet, with a view to giving to the discourse which followed its appropriate mise en scène. He apparently avoids the details given by the other evangelists for this reason; and the heaping up of clauses fixes the complete picture in the reader's mind.

In an authoritative translation it would be inadmissible to recast the sentence in the way here indicated. It would seem, then, that the only course left is so to punctuate that the sentence may be left entire and its meaning preserved. Of course, it is understood that the ancient writing was in uncial letters, without spacing between words, and without punctuation. It is easy, therefore, to see how such a difficulty as that here discussed might have arisen. 